\title{
Structural Characteristics of Rosa lliensis Chrshan. under Conditions of the Floodplains of the Rivers Ili and Sharyn
}

\author{
Assel Childibayeva' ', Abibulla Ametov' ', Natalia Vladimirovna Kurbatova', \\ Aigul Akhmetova', Bekzat Makulbayevich Tynybekov', \\ Gulzhanat Amangeldykyzy Mukanova'
}

\author{
1 Al-Farabi Kazakh National University, Al-Farabi Avenue 71, Almaty 050040, Kazachstan \\ * Corresponding author's e-mail: a.zh.childebaeva@gmail.com
}

\begin{abstract}
The article provides brief geobotanical characteristics of plant communities of three populations of $R$. iliensis Chrshan. found in the floodplains of the Ili and Sharyn rivers, as well as presents the morpho-anatomical structure of vegetative organs (stem and leaf) of the species under study. R. iliensis Chrshan. is undoubtedly a rare, endangered species of the flora of Kazakhstan. Its distribution area is shrinking from year to year as a result of the anthropogenic pressure on the environment. The biometric indicators of vegetative organs in the samples collected from populations 1 and 2 were approximately the same. The indicators of the samples collected from population 3 differed substantially. This is a completely natural process, since there are substantial differences in the climatic conditions of the upper and lower parts of the basin where the Ili River flows: a sharp increase in temperature and a decrease in precipitation from high to low hypsometric levels of the basin. Moreover, there is a gradual aridization of the territory from east to west. Naturally, this entails a change in both soil and vegetation cover as well as leaves its mark on the morpho-anatomical structure of vegetative organs. With this in mind, the authors recommend continuous monitoring of the state of the populations at the three sites where $R$. iliensis Chrshan. was found.
\end{abstract}

Keywords: association, dominant, edificator, phytocenosis, plant anatomy, R. iliensis Chrshan.

\section{INTRODUCTION}

Human societies have been in close contact with their environments since the beginning of their formation and used the ingredients of the environment to obtain food and medicine [Fatemeh Jamshidi-Kia et al., 2018]. Medicinal plants have been used since the ancient times and may even be considered the origin of modern medicine [Salmerón-Manzano, et al., 2020]. It is a fact that all civilizations have developed this form of medicine [Gurib-Fakim, 2006] based on the plants in their own habitat [Houghton, 1995]. There are even authors who claim that this transmitted knowledge is the origin of medicine and pharmacy. Even today, hundreds of higher plants are cultivated worldwide to obtain useful substances in medicine and pharmacy [Kinghorn \& Seo, 2020]. The therapeutic properties of plants gave rise to medicinal drugs made from certain plants with such benefits [Jones et al., 2006].

The medicinal plants play an important role in rural health care system throughout the world in remedying and preventing various kinds of diseases. This study documented the use of plants as traditional herbal medicine in the Kangkar Pulai region Johor, Malaysia. It also identified the homogeneity of informant knowledge on the medicinal plants suitable for different ailments and types of plants most favored for the treatment of each ailment in the study [Alsarhan, et al., 2012].

The therapeutic use of natural products from indigenous plants for ethnomedicinal and nutritional purposes has drawn tremendous interest among scientists to search for bioactive components [Oktay et al., 2003; Wangensteen et al., 2004] that are beneficial to man. Recently, the interest in natural products from plants and their 
use has increased greatly even in the areas where conventional medicines are very much available.

Rosaceae Juss. are well known ornamental plants and have been referred to as the king of flowers [Cai, et al., 2005; Nikbakht et al., 2004]. Rose oil is obtained from the petals of different Rosa species especially Rosa centifolia L. and Rosa damascena Mill. Various pharmacological properties have been attributed to rose oil [Mohebitabar, et al., 2017]. The content of the predominant groups of biologically active substances (tannides, polysaccharides, flavonoids) and bioelements in the aboveground parts of ten species of the Rosaceae family was determined [Krasnov et al., 2017].

Medicinal flora such as, Berberis lyceum, Ajuga bracteosa, Aconitum heterophyllum, Bistorta amplexicaule, Saussurea lapa and Jurinea dolomiaea are on the edge of extinction due to over exploitation [Ahmad \& Habib, 2014].

In recent years, members of the Department of Biodiversity and Bioresources of al-Farabi Kazakh national university have made every effort in conducting the research on some rare and endemic plant species such as Berberis iliensis M. Pop., Lonicerai liensis Pojark., Ferula iliensis Krassin. (F. popovii Korov.), Taraxacumkok-saghyz Rodin. (T. brevicorniculatum V. Korol.), Iris albertii Rgl., Oxytropis almatensis Bajt., Limonium michelsonii Lincz., Ikonnikovia kaufmanniana (Regel) Lincz. at the population level [Mukhitdinov et al., 2014; Ydyrys et al., 2013]. However, each of these species represents different families, so the indicators of morpho-anatomical structures of their vegetative organs were completely different and cannot be compared. As for the species of the Rosa L. Genus, such studies in both geobotanical and morpho-anatomical aspects have not been conducted thus far. Therefore, the conducted research involving the study of Rosa iliensis Chrshan at the population level, is completely new and covers the issues related to the problems of geobotany, morphology and anatomy of plants, as well as the ecology of this species.

In this manuscript, a greater emphasis was placed on the discussion of the anatomical and morphological structure of the vegetative organs of the studied rosehip species. At the same time, brief geobotanical descriptions of plant communities with the participation of Rosa iliensis Chrshan were given. It is known that the morphoanatomical structure of vegetative organs is one of the indicators that determine the adaptability of any species, including the investigated object to certain soil and climatic conditions of the environment. Moreover, any changes in the environment are primarily reflected in the structural features of the plant.

R. iliensis Chrshan. it is one of the rare and endemic plant species of the flora of Kazakhstan, which are under threat of extinction [Winterholler, 1976]. The distribution area of $R$. iliensis Chrshan. has sharply decreased in the last 45-50 years due to the construction of the Kapchagai hydroelectric station on the Ili River. The floodplain of the Ili River is completely flooded, starting from the area of the Ayak-Kalgan resort to the Kapchagai Bridge. An artificial lake named "Kapchagai Reservoir"was formed there with a length of about $160-180 \mathrm{~km}$ and a width of $3-5 \mathrm{~km}$. This led, firstly, to a disjunct distribution area of $R$. iliensis Chrshan., and secondly, to a deterioration of the ecological situation not only in the lower reaches of the Ili River, but also in the entire Southern Balkhash region. The water level in the Ili River below the Kapchagai Hydroelectric Power Station dropped sharply; as a result, the river's floodplain stopped flooding, the water stopped filling the old river channel and its tributaries, and the shallow delta lakes dried up, which led to the disappearance of reed beds, as well as the thinning of tugai (i.e. associated with fluvial and floodplain areas in arid climates), forests and dense impenetrable shrubs. The populations of certain rare and endemic plant species, including $R$. iliensis Chrshan., have deteriorated. In this regard, the goal of searching for and finding the populations of $R$. iliensis Chrshan. in the floodplains of the Ili River and its main left tributary, the River Sharyn, was set to study them in all aspects. Traditional and novel methods of botanical research were employed in order to assess the current state of this rare, valuable, narrowly endemic plant, and thereby make every effort to preserve the natural population of $R$. iliensis Chrshan. and consider the issues of the introduction of this species.

\section{MATERIAL AND METHODS}

The object of conducted study, $R$. iliensis Chrshan., is a mesophilic thorny shrub with semicurly greenish-brown branches, up to $1.5 \mathrm{~m}$ high. Leaves are 6-7 cm long, with 2-3 opposite leaflets. Flowers are white, with pale pink shades, 
clustered or rarely solitary; sepals are furry, 5-7 mm long, apex pointed. Fruits small, always spherical, 5-7 $\mathrm{mm}$ in diameter, bare and smooth, black when ripe, walls very thin, always fall off with a disc [Ametov, 2005; Childibayeva et al., 2019]. R. iliensis Chrshan. blooms for a long time from early May to late October. It is a rare, endemic plant, the fruits of which contain up to 12.5\% of vitamin C [Modern Roses - 12:2007].

The geobotanical descriptions of phytocenoses were carried out using standard methods [Ulanova, 1995]. The study of coenotic populations was carried out by using traditional methods [Mukhitdinov, 2011]. The age structure of coenopopulations was evaluated following T.A. Rabotnov and A.A. Uranov. The coordinates were determined using the GPS device of a GASMAP60CSX navigator. The samples of plant material (stem and leaf) of $R$. iliensis Chrshan. were collected from the three above-mentioned populations for subsequent morpho-anatomical study of the species. The morpho-anatomical features of $R$. iliensis Chrshan. were described according to the generally accepted classifications [Lotova, 2007; Akhmetova et al., 2015; Atabayeva et al., 2016, Aidosova et al., 2018; Seilkhan et al., 2019]. The microscopic studies were conducted using plant material which was fixed in a mixture of alcohol $96 \%$, glycerine and water in a 1: 1: 1 ratio. The methods which are generally accepted in plant anatomy were used in the manufacturing and description of preparations [Barykina \& Veselova, 2004].

Adhering to the guidelines, the cross sections of the vegetative organs were made in the flowering phase, since it is in this phase that the structural anatomical elements of the plant organs have the greatest integrity.

In order to determine the morphological and anatomical features of stems and leaves, microscopic studies were carried out. When characterizing stems, the following features are of particular importance: on a cross-section, at a small magnification (x10) it is necessary to distinguish the primary cortex, most often occupying a large part of the root section and a relatively narrow central cylinder. Their general shape, the shape and structure of cells, as well as the distribution of xylem and phloem elements should be described.

The root sections were made in the basal part of the root along its entire length every $2-3 \mathrm{~cm}$. The middle-age plants in the generative state were taken for the study; the main attention was paid to the plants that provide the bulk of the raw material in the study of species.

The anatomical preparations were made using a microtome with an OL-ZSO freezing device (Inmedprom, Russia), as well as by hand using ordinary razors with a biconcave blade. The thickness of the anatomical sections was 10-15 microns. For quantitative analysis, the morphometric indicators were measured using an MOV-1-15 eyepiece micrometer (with a lens of $\mathrm{x} 10$, magnification of $\mathrm{x} 40,10$, and 7). The microphotographs of anatomical sections were taken on an MC 300 microscope (Micros, Austria) with a CAM V400 / 1.3M video camera (Probe, Japan). The description of external characters was made in accordance with the requirements of the GF XI [The State Pharmacopoeia of the USSR, 1990].

\section{RESULTS AND DISCUSSION}

As a result of an increase in anthropogenic pressure on the environment, the distribution area of $R$. iliensis Chrshan. has sharply decreased. In this regard, it became necessary to study $R$. iliensis Chrshan. at the population level in order to give a scientifically valid assessment of the current state of this rare, endemic plant. During the growing season of 2018, three populations of $R$. iliensis Chrshan. were found in the floodplains of the Ili and Sharyn rivers of the Almaty Region and described in a geobotanical aspect as well as samples of plant material (stem and leaf) were collected for subsequent morpho-anatomical study of the species. A brief description of the plant communities of the three populations found was provided in the geobotanical section of the article.

Population 1 of $R$. iliensis Chrshan. was found in a thick ash tree forest of the Sarytogai tract in the floodplain of the Sharyn River located on the territory of the Sharyn State National Natural Park on the border of the Uigur and Enbekshikazakh districts of the Almaty region. GPS coordinates: N4331'24,4”; E 79¹5'42,7'. A plot was at $629 \mathrm{~m}$ above sea level.

The vegetation cover was formed by the ash and shrub association (ass. Rosa beggeriana, Rosa iliensis, Berberis iliensis-Fraxinus potamophylla). Projective cover was $95-100 \%$. The soils were forest-meadow floodplain. The relief was a low plain inclined to the northeast. The vegetative cover consisted of four layers. The 
first layer was formed by Fraxinus potamophylla Herd. 20-25 m high; the second, by Rosa beggeriana Schrenk. and Rosa iliensis Chrshan. 1.5-3 m high; the third, by Calamagrostis epigeios (L.) Roth, Elymus multicaulis Kar. et Kir. and Glycyrrhiza uralensis Fisch. 100-110 cm high; and the fourth, by Geum urbanum L. and Impatiens parviflora DC. $40-70 \mathrm{~cm}$ high. The dominant species of this forest was one of the oldest species of the modern flora, Fraxinus potamophylla Herd., which survived from the Paleogene era. The area of the forest is 5.04 thousand hectares; it is protected in the rank of a state natural monument. Fraxinus potamophylla Herd. forms a dense tree stand, often without or with a sparse grass layer formed by Calamagrostis epigeios (L.) Roth., Asparagus officinalis L. and Rubus caesius L., Salix capsica Pall., Rosa iliensis Chrshan., Rosa beggeriana Schrenk., as well as two Red Book species, Berberis iliensis M.Pop. and Lonicera iliensis Pojark. are common in the understory.

Population 2 of $R$. iliensis Chrshan. was found in the floodplain of the right bank of the Ili River, not far from the bridge where the AlmatyKhorgos highway passes. The GPS coordinates are as follows: N 435'21.8”; E 79³4'38.2”. The plot was situated at $494 \mathrm{~m}$ above sea level.

The Ili River originates in China; it is the largest waterway in the Almaty region. It belongs to the rivers of mixed feeding. The riverbed is often split into branches and tributaries separated from the main stream by islands covered with reeds, cattail or tree-shrubbery. The site where the Rosa iliensis Chrshan. population was found is located in the upper reaches of the Ili River, not far from the state border between China and Kazakhstan. The tugai type of vegetation along the banks of the Ili River was represented by Elaeagnus oxycarpa Schlecht., Tamarix ramosissima Ledeb., Halimodendron halodendron (Pall.) Voss. and Populus diversifolia Schrenk. communities. The vegetation cover of the $R$. iliensis Chrshan. population is represented by the barberry-rosehip association with a rare participation of Elaeagnus oxycarpa (ass. Rosa beggeriana, Rosa iliensis - Berberis iliensis). The projective cover was $95-100 \%$. The soils were forest-meadow floodplain. The relief was a sloping plain. The vegetation cover consisted of four layers. The first layer was formed by individual representatives of Elaeagnus oxycarpa Schlecht. 10-15 m high; the second, by Berberis iliensis M.Pop., Rosa beggeriana Schrenk. and Rosa iliensis Chrshan. 1.5-3 m high; the third, by
Calamagrostis epigeios (L.) Roth., Glycyrrhiza uralensis Fisch., Asparagus officinalis L. and Apocynum lancifolium Russan. 100-120 cm high; and the fourth, by Geum urbanum L., Impatiens parviflora DC, Lotus frondosus Freyn. $35-70 \mathrm{~cm}$ high. The dominant species were Berberis iliensis M. Pop. and Rosa beggeriana Schrenk.

Population 3 was found in the floodplain of the right bank of the Ili River, below the Kapchagai hydroelectric station, not far from the lowmountain massif of Malaysary. GPS coordinates: N 4409'50,6"; E 076 57'87'. The plot was at $417 \mathrm{~m}$ above sea level.

The vegetation cover was represented by the graminoid-tamarix-rosehip association (ass. Rosa beggeriana, Rosa iliensis-Tamarix ramosissimaPhragmites australis, Calamagrostis epigeios, Achnatherum splendens). The projective cover was $85-90 \%$. The relief was a flat plain. The soil was alluvial meadow, sandy loam. The dominant species were Calamagrostis epigeios (L.) Roth. and Phragmites australis Trin. The vegetation cover consisted of five layers. The first layer was formed by Elaeagnus oxycarpa Schlecht. and $\mathrm{Sa}$ lix caspica Pall. $3.5 \mathrm{~m}$ high; the second, by Tamarix ramosissima Ledeb., Rosa beggeriana Schrenk., and Rosa iliensis Chrshan., 150-220 cm high; the third,' by Phragmites australis Trin. and Calamagrostis epigeios (L.) Roth., 90-100 cm high; the fourth, by Artemisia scoparia Waldst. et Kit and Cannabis ruderalis Janisch. 60-70 cm high; and the fifth, by Eremopyrum orientale (L.) Jaub. et Spach., Allyssum desertorum Stapf., Trifolium pratense L. and Arnebia decumbens (Vent.) Coss. et Kral. 10-15 cm high.

The next stage of the work was the anatomical study of the leaf blade and stem of $R$. iliensis Chrshan.

In the cross section, the leaf blade of $R$. iliensis Chrshan. had a single-layer epidermis consisting of oblong-shaped cells with numerous and single simple hairs. In the plants from population 3 , the hairs were found in much larger quantities. The epidermal cells were tightly connected and covered with a thin layer of cuticle. The walls of epidermal cells were slightly sinuous. The palisade mesophyll consisted of two rows and was located under the upper epidermis, the cells of the spongy mesophyll were located under the columnar mesophyll of the leaf blade and had a loose structure; the cells were small, with numerous intercellular spaces filled with air, elongated and few. In the plants of the three populations, idioblasts were 
noted in the structure of leaf blades; the idioblasts were located mainly under the layer of columnar mesophyll, along the central part of the leaf blade. The idioblasts could be distinguished among the parenchymal tissue by their size, isodiametric, sometimes almost spherical shape and a unique content (Fig. 1).

The conductive bundles were collateral, closed, located in the center of the leaf blade. The conductive bundles had a thin lining formed by sclerenchymal cells. The structure of the leaf blade was of the same type, the difference laid in the severity of xeromorphic features of the structure in plants from the third population. When comparing the biometric data (Table 1), a difference in indicators was noted. Therefore, the plants from the first and second populations had similar biometric data, and the plants from the third population differed in all considered indicators. The layers of parenchymal cells were most pronounced in the plants growing in populations 1 and 2 .

During the anatomical study of the stem, the following features were noted: in a cross-section, the shape of the stem was round and slightly ribbed. On the cross section, the stem of $R$. iliensis Chrshan. had the following structure: the stem was covered with a skin with a thickened cuticle on the outside; the development of the cuticle was connected with the rather arid growing conditions of $R$. iliensis Chrshan. The skin cells were rounded, with much thickened walls. Under the cuticle, there was one row of larger epidermal cells, followed by 2-3 layers of collenchymal cells. Below them there was the collenchymatized parenchyma of the primary cortex consisting of 4-5 rows of homogeneous (populations 1 and 2) or 6-7 rows of loosely arranged (population 3 ) isodiametric cells. The cells of the main parenchyma were larger, rounded-oblong or oval in a)



b)

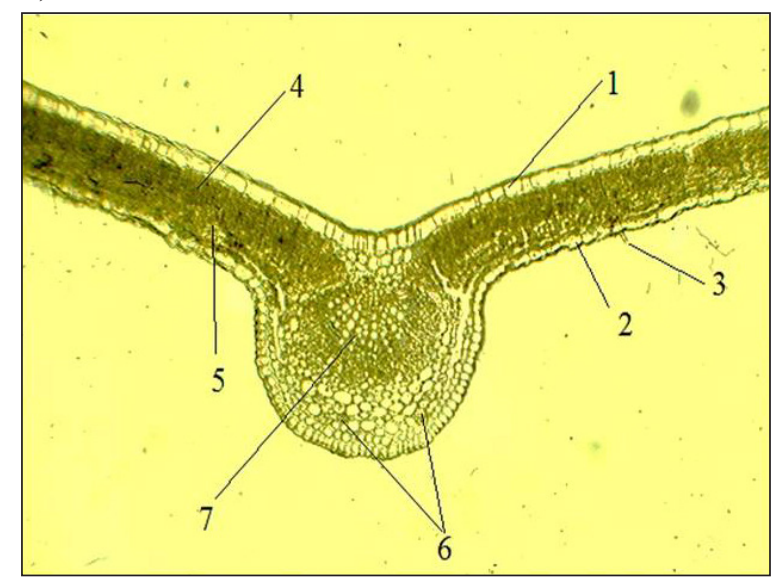

c)



Figure 1. Anatomical structure of the R. iliensis Chrshan. Leap (magnification of x200): 1 - upper epidermis, 2 - lower epidermis, 3 - simple hairs, 4 - palisade mesophyll, 5 - spongy mesophyll, 6 - idioblasts, 7 - conducting bundle, 8 - sclerenchymic lining of the conducting bundle 
Table 1. Biometric data of the leaf blade of R. iliensis Chrshan

\begin{tabular}{|c|c|c|c|c|c|c|}
\hline \multirow{2}{*}{ Population } & \multirow{2}{*}{$\begin{array}{c}\text { Sheet thickness, } \\
\text { microns }\end{array}$} & \multicolumn{2}{|c|}{ The thickness of the epidermis, microns } & \multicolumn{2}{|c|}{ Mesophyll thickness, microns } & \multirow{2}{*}{$\begin{array}{c}\text { Area of conductive } \\
\text { beams, } \times 10^{-3} \mathrm{Mm}^{2}\end{array}$} \\
\hline & & Upper & Lower & Palisade & Spongy & \\
\hline 1 & 551.5 & 1 & 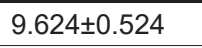 & 629 & 102.1 & 558 \\
\hline 2 & 533.2 & 35 & 20 & $80.317 \pm 30.255$ & 122.118 & 876 \\
\hline 3 & $512.359 \pm 8.312$ & $8.102 \pm 0.233$ & $6127 \pm 0.124$ & $65.367 \pm 24.211$ & $98.238 \pm 10.451$ & $231.212 \pm 60.639$ \\
\hline
\end{tabular}

shape, with thick walls. The bottom row of cells adjoined the bast fibers arranged in groups. This was followed by a continuous layer of the outer phloem followed by a layer of cambial cells, followed by xylem vessels. The conductive bundles were terminated by the internal phloem, which was represented by the areas under each conductive bundle. It should be noted that the main part of the central cylinder was occupied by partially merged vascular-fibrous bundles of the collateral type. The cambium layer was visible between the secondary phloem and secondary xylem. In longitudinal sections, the secondary phloem was represented by large sieve tubes and thin-walled bast parenchyma. The secondary xylem consisted of reticular vessels, tracheids with bordered pores and wood fibers with simple pores. The vessels of the primary xylem directly adjacent to the core had annular and spiral thickening of the walls. The main biometric indicators of the stem included: the thickness of the primary cortex, the diameter of the central cylinder and the area of xylem vessels, the biometric indicators of which are presented in table 2. In the thickness of the central cylinder, core cells with stony idioblast cells were noted (Fig. 2). Table 2 shows the similarity of the biometric indicators of populations 1 and 2 .

\section{CONCLUSIONS}

The study in a comparative aspect of the morpho-anatomical structure of the aboveground vegetative organs (stem and leaf) of $R$. iliensis Chrshan. collected from three different populations of the floodplains of the Ili and Sharyn rivers located at a great distance and at different heights above sea level showed that $R$. iliensis Chrshan. is a true mesophyte. This is evidenced, firstly, by the confinement of this species to the floodplains of the Ili and Sharyn rivers, and secondly, by the special features of the anatomical structure of its leaf blade and stem. The biometric indicators of the leaf blade of $R$. iliensis Chrshan. in the samples collected from populations
1 and 2 had approximately the same values. This applies to the thickness of the leaf, the thickness of its upper and lower epidermis, the thickness of the palisade and spongy mesophyll, as well as the area of the conducting bundles. According to these indicators, the leaf sample of $R$. iliensis Chrshan. collected from population 3 is not inferior to the leaf samples collected from populations 1 and 2. Moreover, trichomes of the epidermis of the leaf from the third population are very conspicuous and quite long; they densely cover the surface of the leaf. This is a completely natural process, as the third population of $R$. iliensis Chrshan. in the floodplains of the lower reaches of the Ili River was found at a higher and more open location, somewhat remote from the river bank, where there was no shading effect of the trees that made up the tugai forest. Hence, the more xerophytic character of $R$. iliensis Chrshan. from the third population. This is generally confirmed by the features of the anatomical structure of the $R$. iliensis Chrshan. stem. As indicated by the biometric data, the thickness values of the primary cortex of the stem in the first and second populations were almost the same. The diameters of the central cylinder and the conducting beams had similar indicators. According to these indicators, the third population of $R$. iliensis Chrshan. was inferior to the first and second populations.

This is a completely logical process, since the upper part of the Iliysky intermountain basin - where two populations of $R$. iliensis Chrshan. were discovered and described, is considered as an enclave of the Dzungarian province. The flat part, where the third population of this species was described, belongs to the East Severo-Turan sub-province of the North-Turan province of the Iran-Turan desert sub-region within the SaharaGobi desert region. One of the structural features of the relief of the Iliysky intermountain basin is a significant difference in elevations on the plains: from 1500 to $500 \mathrm{~m}$ above sea level at a short distance $(50-60 \mathrm{~km})$. Significant differences in the climatic conditions of the upper and lower parts of the basin are observed: a sharp increase in 
a)

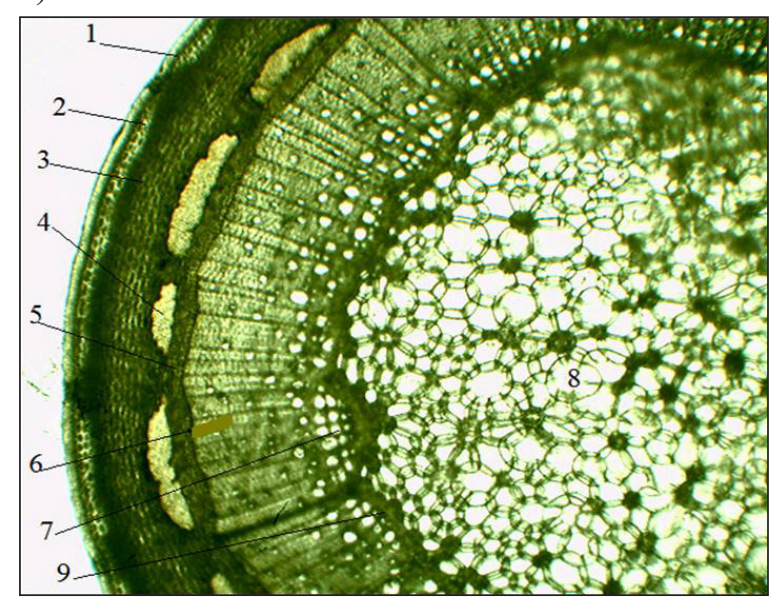

b)

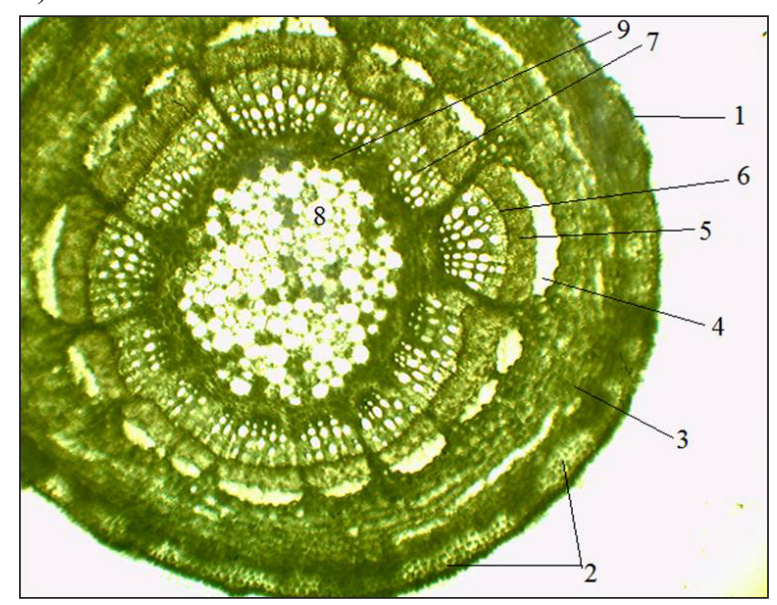

c)

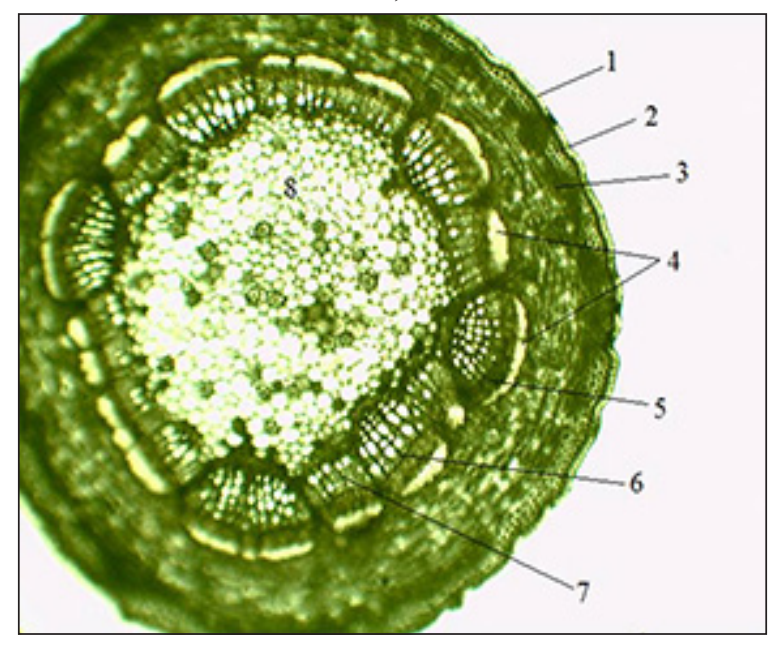

Figure 2. Anatomical structure of the R. iliensis Chrshan. stem (magnification of x140): 1 - epidermis, 2 - collenchyma, 3 - collenchymatized parenchyma of the primary cortex, 4 - group of bast fibers, 5 - external phloem, 6 - cambium, 7 - xylem, 8 - core cells with stony cells, 9 - internal phloem

temperature and a decrease in precipitation from the high parts of the basin to low hypsometric levels. There is also a gradual aridization of the territory from east to west.

On the whole, the study of the morpho-anatomical structure of the aboveground vegetative organs (stem and leaf) of $R$. iliensis Chrshan. collected from the three different populations of the floodplains of the Ili and Sharyn rivers showed that a slightest change in the terrain, soil cover, its physicochemical composition, soil and air humidity, especially the temperature regime, entails changes in the vegetation cover and its floristic composition. Moreover, this is reflected to a certain extent in the morpho-anatomical structure of the vegetative organs of plants. More tolerant and flexible species easily adapt to new environmental conditions, while less adapted species take root poorly and gradually fall out of the plant community. This applies to all life forms of plants, including tree and shrub species. It can be said that this $R$. iliensis Chrshan. belongs to more tolerant and flexible species. It adapts well to the existing ecological conditions of the environment and successfully reproduces both by seed and vegetatively.

Table 2. Biometric data of the stem of $R$. iliensis Chrshan

\begin{tabular}{|c|c|c|c|}
\hline Population & $\begin{array}{c}\text { The thickness of the primary cortex, } \\
\text { microns }\end{array}$ & $\begin{array}{c}\text { Diameter of the central } \\
\text { cylinder, microns }\end{array}$ & $\begin{array}{c}\text { Area of conductive beams, } \\
\mathrm{x} 10^{-3} \mathrm{~mm}^{2}\end{array}$ \\
\hline 1 & $50.525 \pm 3.265$ & $343.225 \pm 3.265$ & $41.564 \pm 9.321$ \\
\hline 2 & $49.658 \pm 3.017$ & $322.556 \pm 1.751$ & $42.597 \pm 5.385$ \\
\hline 3 & $45.238 \pm 2.201$ & $296.114 \pm 2.789$ & $35.715 \pm 8.641$ \\
\hline
\end{tabular}




\section{REFERENCES}

1. Ahmad K.S., Habib S. 2014. Indigenous knowledge of some medicinal plants of Himalaya region, Dawarian Village, Neelum Valley, Azad Jammu and Kashmir, Pakistan. Univ J Plant Sci, 2(2), 40-47. (in English)

2. Aidosova S.S., Akhtaeva N.Z., Tuleuova G.K.H., Ahmetova A.B., Tazhibay A.M., Shaushekov Z.K., Shurupova M.N., Adekenov S.M. 2018. Comparative morphological and anatomical characteristics of Saussurea amara (L.) DC. and S. salsa Pall. Spreng. Pak. J. Bot., 51(1). (in English). DOI: 10.30848/ Pjb2019-1

3. Akhmetova A., Mukhitdinov N., Ydyrys A. 2015. Anatomical indicators of the leaf structure of Ferula iliensis, growing in the eastern part of Zailiyskiy Alatau (Big Boguty Mountains). Pak. J. Bot., 47(2), 511-515. (in English)

4. Alsarhan A., Sultana N., Kadir M.R.A., Aburjai T. 2012. Ethnopharmacological survey of medicinal plants in Malaysia, the Kangkar Pulai region. Int J Pharmacol, 8(8), 679-686. (in English)

5. Ametov A. 2005. Botany. Dauir Publishing House. Almaty, 511. (in Kazakh)

6. Atabayeva S., Lee T., Nurmahanova A., Akhmetova A., Narmuratova M., Asrandina M., Beisenova A., Alybayeva R. 2016. Anatomical peculiarities in wheat (Triticum aestivum L.) varieties under copper stress. Pak. J. Bot., 48(4), 1399-1405. (in English)

7. Barykina R.P., T.A. Veselova. 2004. Reference book on botanical microtechnology. Moscow, PH MSU, 322. (in Russian)

8. Cai Y.Z., Xing J., Sun M., Zhan Z.Q., Corke H. 2005. Phenolic antioxidants (hydrolyzable tannins, flavonols, and anthocyanins) identified by LC-ESIMS and MALDI-QIT-TOF MS from Rosa chinensis flowers. J Agric Food Chem., 53, 9940-9948. (in English)

9. Childibayeva A.Zh., Ametov A.A., Tynybekov B.M. 2019. Characteristics of some plant communities involving the narrow-endemic species Rosa iliensis Chrshan in the floodplains of the Ili river. Al-Farabi Kazakh National University Experimental Bilogy. Biology series. Almaty, 1(78), 58-73. (in Kazakh)

10. Gurib-Fakim A. 2006. Medicinal plants: Traditions of yesterday and drugs of tomorrow. Mol. Asp. Med. 27, 1-93. (in English)

11. Houghton P.J. 1995. The role of plants in traditional medicine and current therapy. J. Altern. Complementary Med., 1, 131-143. (in English)

12. Jamshidi-Kia F., Lorigooini Z., Amini-Khoei H. 2018. Medicinal plants: Past history and future perspective Zahra Lorigooini . Journal of Herbmed Pharmacology, 7(1), 1-7. (in English)
13. Jones W.P., Chin Y.W., Kinghorn A.D. 2006. The role of pharmacognosy in modern medicine and pharmacy. Curr. Drug Targets., 7, 247-264. (in English)

14. Kinghorn A.D., Seo E.K. 2020. Plants as Sources of Drugs. ACS Symposium Series, Vol. 647. Agricultural Materials as Renewable Resources, Chapter 12, 179-193. https://pubs.acs.org/doi/abs/10.1021/ bk-1996-0647.ch012 (accessed on 12 May 2020). (in English)

15. Krasnov E.A., Saveleva E.E., Ryzhakova N.K., Reshetov Y.E., Gataullina A.R. 2017. Investigation of the content of the dominant groups of Biological active substances and Bioelements in some plants of the Rosaceae family. Chemistry of plant raw materials, 4, 141-151. (in Russian)

16. Lotova L.I. 2007. Botany. Morphology and anatomy of higher plants: Textbook. 3rd ed. Moscow. 510. (in Russian)

17. Modern Roses. 2007. The Comprehensive List of Roses in Cultivation or of Historical or Botanical Importance. M.A. Young, Ph. Schorr (Eds.). Shreveport. The American Rose Society, 576. (in English)

18. Mohebitabar S., Shirazi M., Bioos S., Rahimi R., Malekshahi F., Nejatbakhsh F. 2017. Therapeutic efficacy of rose oil: A comprehensive review of clinical evidence. Avicenna J Phytomed., 7(3), 206-213. (in English)

19. Mukhitdinov N.M. 2011. Geobotany. Almaty: RBC "Dauir" LLP, 384. (in Kazakh)

20. Mukhitdinov N.M., Karasholakova L.N., Kurmanbayeva M.S. 2014. The number and the age structure of rare endemic species cenopopulation Lonicera iliensis Pojark. Life Science Journal, 11(6), 459-463. (in English)

21. Nikbakht A., Kafi M., Mirmasoudi M., Babalar M. 2004. Micropropagation of Damask rose (Rosa damascena Mill.) cvs Azaran and Ghamsar. International J of Agriculture and Biology, 7(4), 535-538. (in English)

22. Oktay M., Gülçin I., Küfrevioglu O.I. 2003. Determination of invitro antioxidant activity of fennel (Foeniculum vulgare) seed extracts. Journal of Advanced Scientific Research, 36, 263-271. (in English)

23. Salmerón-Manzano E., Garrido-Cardenas J.A., Manzano-Agugliaro F. 2020. Worldwide Research Trends on Medicinal Plants Int. J. Environ. Res. Public Health., 17, 3376. (in English)

24. Seilkhan A.S., Kudrina N.O., Cherepkova N.V., Kulmanov T.E., Kurmanbayeva M.S., Inelova Z.A., Shalgimbayeva S.M. 2019. Anatomical and morphological structure of Peganum harmala of Almaty region and its therapeutic properties. Pak. J. Bot., 51(2): 649-655. (in English) 
25. The State Pharmacopoeia of the USSR. 1990. Nauka, 11(2), 250. (in Russian).

26. Ulanova N.G. 1995. Mathematical methods in geobotany. Moscow: MGU, 190. (in Russian)

27. Wangensteen H., Samuelsen A.B., Malterud K.E. 2004. Antioxidant activity in extracts from coriander. Food Chemistry, 88, 293-297. (in English)
28. Winterholler B.A. 1976. Rare plants of Kazakhstan. Alma-Ata. Nauka, 200. (in Russian)

29. Ydyrys A., Mukhitdinov N.M., Ametov A.A., Tynybekov B.M., Akhmetova A.B., Abidkulova K.T. 2013. The States of coenpopulations of endemic, relict and rare species of plant Limonium michelsonii and their protection. World Applied Sciences Journal, 26(7), 934-940. (in English) 